\title{
Climate Impacts, Political Institutions, and Leader Survival: Effects of Droughts and Flooding Precipitation
}

\author{
Oleg Smirnov ${ }^{1 *}$, Martin C. Steinwand ${ }^{2}$, Tingyin Xiao ${ }^{3}$, Minghua Zhang ${ }^{4}$ \\ ${ }^{1}$ Department of Political Science, Stony Brook University, Stony Brook, NY 11794, USA. \\ ${ }^{2}$ Department of Government, University of Essex, Wivenhoe Park, Colchester CO4 3SQ, UK \\ ${ }^{3}$ Woodrow Wilson School of Public and International Affairs, Princeton University, Princeton, \\ NJ 98540, USA. \\ ${ }^{4}$ School of Marine and Atmospheric Sciences, Stony Brook University, Stony Brook, NY 11794, \\ USA. \\ *Correspondence to: oleg.smirnov@stonybrook.edu \\ The authors are listed alphabetically. T.X., M.Z., and O.S. generated the climate data. O.S. and \\ M.S. performed data analysis and wrote the paper.
}

\begin{abstract}
We explore how the political survival of leaders in different political regimes is affected by drought and flooding precipitation, which are the two major anticipated impacts of anthropogenic climate change. Using georeferenced climate data for the entire world and the Archigos dataset for the period of 1950-2010, we find that irregular political exits, such as coups or revolutions, are not significantly affected by climate impacts. Similarly, drought has a positive but insignificant effect on all types of political exits. On the other hand, we find that floods increase political turnover through the regular means such as elections or term limits. Democracies are better able to withstand the pressures arising from the economic and social disruptions associated with high precipitation than other institutional arrangements. Our results further suggest that, in the context of floods, political institutions play a more important role than economic development for the leaders' political survival.
\end{abstract}

\section{Acknowledgments}

This project is funded by the National Science Foundation award \#0940822. An earlier version of the paper was presented at American Political Science Association 2015 annual meeting in San Francisco, CA. 
As severe consequences of anthropogenic climate change for human societies become a near certainty (IPCC, 2014), adaptation to changed environmental conditions becomes a necessity for affected societies. The need to pay for disaster preparedness and impact adaptation raises issues of the socialization of private costs (Neumayer et al., 2014), and some societies will have to deal with resettlement pressures (Black et al., 2011; McLeman \& Smit, 2006; PerchNielsen et al., 2008). Climate change therefore puts a variety of pressures on political systems that are yet little understood. One important predicted change in weather patterns is an increase in the number of extreme weather events (Hirabayashi et al., 2013; Prudhomme et al., 2014). The Intergovernmental Panel on Climate Change (IPCC) provides reliable evidence that individual regions are beginning to experience more intense and longer droughts and more extreme precipitation events (IPCC, 2014). How governments handle droughts and floods provides a window into how political systems are able to deal with political pressures arising from dealing with meteorological phenomena that will become more frequent and pronounced as a consequence of climate change.

To study these responses, in this article we explore how drought, based on the degree and duration of dry atmospheric conditions (Mishra \& Singh, 2010; Vicente-Serrano et al., 2009), and precipitation, due to heavy rain (Brakenridge, 2014; Hirabayashi et al., 2013), affect the survival of political leaders in office (Goemans et al., 2009). Removal from office is a strong political sanction that leaders face for unsatisfactory performance in office (Goemans, 2008). However, only some crises caused by drought or flooding precipitation result in political punishment due to different institutional, economic, and demographic contexts. Here we study the political consequence of extreme weather events across countries and isolate the effects of important political and economic variables. In particular, we are interested in whether political 
institutions make democratic leaders more sensitive to the adaptation pressures of climate change than their authoritarian counterparts. Also, we would like to know whether wealthier countries are better able to deal with these political pressures than poorer societies.

We focus on wealth and democracy because there is a wide consensus that natural disasters have worse effects on populations in developing countries (Burkett, 2012; IPCC, 2014; Kahn, 2005), largely because their governments lack the financial means and institutional capacity to prepare for extreme events. This suggests that wealth and regime type play an especially crucial role for adapting to greater climate volatility in developing countries. Existing works also show important effects of political regime type on disaster preparedness. For example, Flores \& Smith (2013) establish that democratic governments get politically punished for natural disasters if the latter result in a high number of casualties, whereas non-democratic leaders face more protests over natural disasters independent of casualty rates. The authors argue that this difference in the political risks associated with extreme weather events induce democratic governments to invest in disasters preparedness, but not their non-democratic counterparts. Further support for political damage caused by natural disasters comes from a micro-level study of the 2010 forest fires in Russia and their effect on local electoral behavior (Lazarev et al., 2014).

Another strand of the literature paints a different picture. There is evidence that democratic leaders reap political rewards if they show competence in managing the aftermath of disaster and ensure swift compensation for damages (Bechtel \& Hainmueller, 2011; Healy \& Malhotra, 2009). In contrast to Flores and Smith (2013), Healy and Malhotra (2009) conclude that this political benefit leads to a reduction - rather than an increase - in disaster preparedness in democracies. 
Neither of the existing works is based on large-scale, objective meteorological disaster data, which might help explain these contradictory results. Our study is the first to connect comprehensive georeferenced meteorological data to the question of leader survival in the aftermath of extreme weather events.

Not all natural disasters are alike. Intuitively, there should be a connection between the scope and speed with which a disaster unfolds and its political consequences. Several small and slowly occurring changes to the environment might result in constituents paying little attention because the salience of these changes is low. Even if the changes are noticed, constituents might prefer not to take political action because the relative costs of doing so are too high. Eventually, the consequences of a slowly unfolding environmental disaster might become too severe to be ignored. But even in this scenario assigning accountability to the government is not straightforward if policies were implemented a long time ago by past incumbents. In contrast, quickly occurring disasters that produce high numbers of casualties and other costs pass the threshold for political action more easily. For example, Neumayer et al. (2014) show that economic losses from strong natural disasters with sudden onset (earthquakes, floods, and tropical cyclones) are smaller for countries with greater disaster propensity as leaders react to political pressures ${ }^{1}$. Leader survival therefore might be more sensitive to sudden-onset natural disasters compared to those that arise slowly.

Droughts and floods also differ in other ways. Poor countries tend to have larger agricultural sectors. In these countries, drought can have severe consequences as it leads to

\footnotetext{
${ }^{1}$ Notably, however, Neumayer et al. do not distinguish between different political institutions, using GDP and per capita income as the two control variables.
} 
repeated crop failures and dwindling of live stocks (Kelley et al., 2015; Mavromatis, 2007; Reyna, 2010; Svoboda et al., 2002). In contrast, in industrialized economies drought will cause inconveniences, such as limitations on water use for lawn maintenance and the like, but short of catastrophic conditions in which drinking water supplies are not guaranteed, the impact on the economy may be relatively small. Flooding tends to be geographically more limited than drought, and therefore has on average less potential to disrupt agricultural production.

Our choice of leader survival as key dependent variable follows a burgeoning literature that has used leader survival as a measure of political success in a wide variety of fields such as international conflict research (Chiozza \& Goemans, 2004), the political economy of development (Bueno de Mesquita \& Smith, 2009), and foreign aid decision making (Licht, 2010), among others. We contribute to this literature by providing a fine-grained analysis of how extreme weather events affect leader survival in different economic and political regimes.

Important previous work in this vein is Flores and Smith (2013), who relate natural disaster response to leader survival, and Chang and Berdiev (2015), who look at leader removal in the wake of disaster. In both cases, the authors focus on the impacts of natural disasters, such as the numbers of killed and displaced people. We choose a different strategy, by directly measuring meteorological events. Our approach has the advantage of accounting for all droughts and floods, regardless of whether they produce casualties or not. This eliminates an important source of selection bias, since casualty numbers and disaster responses may be correlated with political regime type and wealth. It also helps to avoid problems with inconsistencies in the 
quality of data reporting. ${ }^{2}$ In addition, our measures of drought (based on the Standardized Precipitation-Evapotranspiration Index, or SPEI, (Vicente-Serrano et al., 2009)) and precipitation flooding (Harris et al., 2014) may be used as a historical basis for the future projections of climate change impacts (Taylor et al., 2011).

Our paper also answers calls for increased scrutiny of the political processes that accompany adaptation efforts to climate change. ${ }^{3}$ Javeline (2014) notes that adaptation is "fundamentally political“ (p. 1) as protection measures affect constituents unevenly and therefore have redistributional consequences. By focusing on political survival we explore how extreme weather phenomena affect the most basic incentive mechanism common to leaders in all political regimes across time and space. If drought and flooding constitute a threat to the political survival

${ }^{2}$ Both Flores \& Smith (2013) and Chang \& Berdiev (2015) rely on the Emergency Events Database (EM-DAT), which reports population impacts based on information provided by UN agencies, non-governmental organization, insurance companies, research institutes and press agencies (D. Guha-Sapir et al., 2015). The accuracy of the impacts data - such as the number of people killed, displaced, or requiring emergency assistance - depends on the quality of global monitoring and reporting of the relevant disasters. In addition, Chang and Berdiev employ a conditional logit model that is problematic because it does not explicitly account for time dependencies in the data, and therefore might produce overly optimistic results (Beck et al., 1998).

${ }^{3}$ By convention, "adaptation" refers to measures that deal with the consequences of climate change, whereas "mitigation" aims to curb or halt the process of climate change itself (IPCC, 2014). 
of incumbents, the political benefits of adapting to such natural disasters might outweigh the costs. On the other hand, if leaders are relatively immune to political fallout from extreme weather events, they have little incentive to implement adaptation measures.

Finally, our work speaks to the growing literature on climate change and violent domestic conflict (Buhaug, 2010; Hsiang et al., 2013; Kelley et al., 2015; Solow, 2013). Although leader survival and conflict are conceptually separate, the removal of a leader from office can contribute to the destabilization of the existing political regime, especially if regular institutional rules are violated in the process.

\section{CLIMATE IMPACTS, POLITICAL REGIME AND LEADER SURVIVAL}

A basic insight from the study of electoral politics is that voters can influence leader actions by holding them responsible retrospectively for policy outcomes (Ferejohn, 1986). This motivates the study of political leader survival in the aftermath of extreme weather events. Pioneering work by Achen and Bartels (2004) shows that American voters punish incumbents for spells of drought at the ballot box. This suggests a straightforward logic of how extreme weather events are connected to climate change adaptation. Those leaders who are more susceptible to suffer politically from flooding and drought should be more willing to invest political capital into adaptation measures that alleviate the consequences of increasingly frequent extreme weather events (Neumayer et al., 2014). We also focus on factors that may be moderating this relationship, namely, (a) political regime type, (b) wealth, and (c) the pace of the disaster.

Beginning with regime type, a hallmark that sets apart democratic from non-democratic regimes is that democratic leaders lose elections and voluntarily give up power (Przeworski et al. 
2000). In contrast, leader removal in non-democratic regimes can follow a variety of patterns, that may involve elections (e.g. in one-party states or other illiberal electoral regimes), may follow publicly known rules (e.g., the Chinese Communist Party changes its leadership every 10 years), or are a function of private machinations among ruling elites (prominent examples include the frequent changes of government figureheads under Argentina's military junta from 1976-1982, and the choice of Communist Party leaders in the Soviet Union). The literature on leader survival differentiates between regular and irregular means of removal from office, but these modes of removal mean vastly different things in different political regimes.

Leaders in non-democratic regimes survive in office longer than their democratic counterparts (Bueno de Mesquita et al. 2003). This is not surprising, because regular removal from office for democratic leaders involves elections or term limits, whereas regular removal in non-democratic regimes involves rules that are meant to ensure the ongoing hold on power of the ruling elites (Chiozza \& Goemans, 2004). Removal from office in both democracies and nondemocracies counts as irregular if it happens in a manner that violates existing rules. However, non-democratic rulers are much more likely to be removed in an irregular manner than their democratic counterparts (Goemans, 2008). Together, these trends give rise to intuitive patterns. Democratic leaders are removed from office more frequently and by regular means, whereas non-democratic rulers hang on longer, but tend to exit in non-regular fashion.

What implications do these patterns have for how sensitive rulers in different regimes are to the effects of extreme weather events? The answer is not straightforward. Democratic leaders are held accountable by the electorate in frequent elections and therefore face consistent pressures to accommodate constituent concerns. However, the relationship between natural catastrophes and leader survival is moderated by the role of disaster preparedness, leading to 
contradictory pressures. One the one hand, democratic leaders face political punishment and removal from office if catastrophes result in large casualty numbers (Flores \& Smith, 2013). This provides incentives to improve disaster preparedness. Indeed, countries that experience frequent and strong natural disasters suffer lower economic damage (Neumayer et al., 2014), suggesting better preparedness. On the other hand, voters also reward competent handling of crises in the aftermath of natural disasters (Bechtel \& Hainmueller, 2011). This creates incentives for democratic leaders to reduce, not increase, disaster preparedness (Healy \& Malhotra, 2009). Taken together, these findings suggest that natural disasters may constitute a political opportunity for skilled democratic leaders, but constituents will punish a lack of preparation or failed emergency response. Extreme weather events therefore always present a political risk, which may result in the removal from office through regular channels.

In contrast, in non-democracies leaders are generally shielded against the threat of electoral loss. However, losing an election pales in comparison to the personal consequences that typically come with irregular removal from office. Goemans (2008) shows that fully $80 \%$ of leaders that are removed in irregular fashion face punishment, ranging from exile to execution. Since non-democratic leaders are more likely to be removed in an irregular manner, this threat of punishment should make them susceptible to pressures arising from extreme weather events as well. However, it is important to keep in mind that irregular removal is not the only way how non-democratic leaders can lose office. Some non-democratic regimes have regular mechanisms to exchange leaders while maintaining the regime's power base, such as swapping figureheads in a military junta. In the presence of political pressures, it might be preferable for the regime to change leaders through such regular channels to prevent the greater dangers of irregular removal and regime failure. 
Given the discussion above, we believe that democratic leaders are more sensitive to the risk of regular removal associated with extreme weather events. In contrast, non-democratic leaders must be more concerned with irregular removal. However, since both extreme weather events and irregular removal—even in a non-democracy—are rare events, irregular removal due to a climatological disaster is very unlikely. As a result, we expect authoritarian leaders to discount the importance of natural disasters and to generally under-invest in disaster mitigation and adaptation policies. This doesn't mean that extreme weather events are politically cost free. Flores \& Smith (2013) show that natural disasters in non-democracies are associated with more protests than in democracies. One way to deal with political pressures is to change the leader in a regular manner, thus avoiding the risk of irregular removal and regime failure. We therefore predict that non-democratic leaders are vulnerable to regular removal but less so to irregular removal.

In contrast, democratic leaders face regular removal every few years. As we discussed above, they have greater incentives to invest in disaster preparation policies, but also stand to gain politically from skillful disaster management. Although constituents can punish failed emergency responses, such policies should ameliorate the consequences of natural disasters and reduce the risk of removal from office compared to non-democratic regimes. Our theoretical approach is therefore closer to Flores and Smith (2013) than Healy and Malhotra (2009). Consequently, we test the following hypotheses: (general) H1: Extreme weather events increase the risk of removal from office. (specific) H2: Extreme weather events have a greater effect on the risk of regular removal from office in non-democratic societies. 
A second variable that moderates the impact of natural disasters on leader survival is wealth (Kahn, 2005). There are at least two connections. Governments in wealthier countries tend to have greater capacity to implement policy changes. One reason for this is that they rely less on patronage but on broader winning coalitions and public accountability (Bueno de Mesquita et al., 2003). There also is evidence that good institutions are a prerequisite for growth (Acemoglu et al., 2001), providing a reversed explanation for why wealthier countries tend to be better governed. Irrespective of the actual direction of the causal arrow between government capacity and wealth, governments of wealthier countries should be better at dealing with the effects of extreme weather events, isolating leaders in these countries more from political fallout.

The second connection between wealth and leader survival stems from the ability to use money to pay off important constituent groups. There is broad-based evidence that nondemocratic leaders who have access to outside funding use it to isolate themselves from political unrest, for example if they receive foreign aid (Bueno de Mesquita \& Smith, 2009; Licht, 2010; Morrison, 2009) or oil revenue (Ross, 2001). ${ }^{4}$

While the two connections affect different parts of the causal pathway leading from extreme weather events to leader survival, both point to the same observational outcome. Leaders in wealthier societies should be better able to resist political pressures from extreme climate events either because of better advance preparation and adaptation efforts, or because they can use money to buy support of important constituent groups in the aftermath of disaster. We summarize this discussion in Hypothesis 3.

\footnotetext{
${ }^{4}$ Some exceptions exist. For example, non-democratic leaders can exploit donor preferences for political stability to trade higher political risk for greater rent extraction (Steinwand, 2014).
} 
H3: Leaders in wealthier societies are less at risk from regular or irregular removal following extreme weather events than those in poorer societies.

Finally, we investigate a third major dimension along which political responses to extreme weather events are likely to vary. Natural disasters differ in how they unfold over time, ranging from brief sudden-onset events like the proverbial lightning 'bolt from the blue', to events that are long-lasting and characterized by slowly unfolding consequences, such as the slow spread of an invasive species or changes to regional precipitation patterns brought on by deforestation. The political reactions of affected populations are likely to differ with temporal dynamics.

Unexpected, fast moving, and costly events are difficult to ignore. They potentially impose high costs in terms of life and property, require an immediate disaster response and are therefore of great salience. In comparison, slow moving and long-lasting processes impose fewer costs in the short run, and might not require immediate intervention. This might translate into lower political pressure emanating from affected populations and in turn delay government reactions. As we mention in the introduction, despite the intuitive appeal of these two prototypical scenarios, the literature seems to have paid no attention to differences in how disasters unfold. We attempt to capture both scenarios by looking at extreme weather events that fall on either side of the fast/slow divide. Precipitation flooding often occurs without much forewarning and can destroy the livelihoods of affected populations within a single day (Ashley \& Ashley, 2008; Jonkman \& Kelman, 2005; Kirsch et al., 2012; Komori et al., 2012). Drought on the other hand results from rain (or snow) falls staying below long-term averages for months, years, or even decades (Kelley et al., 2015; Mishra \& Singh, 2011). 
However, the effect of the pace of a natural disaster may vary depending on the regime type and wealth of the country. As we discussed above, democratic states tend to have disaster preparation policies in place which would moderate the damage associated with all types of natural disasters. Conversely, non-democratic leaders-under-investing in disaster mitigation/adaptation - may be able to respond to a slow moving problem but not to a sudden stress. We test this logic using the following hypothesis:

H4: Non-democratic leaders are more vulnerable to sudden natural disasters (such as flooding precipitation) than democratic leaders.

Notice that all hypotheses above are based on the two types of climate impacts that we study: extreme drought and flooding precipitation. We hope that our theory and results apply to other types of fast and slow natural disasters; nevertheless, we urge caution when interpreting and generalizing from our findings (for example, in the context of heat-stress and sea-level rise as, respectively, fast and slow disasters), which is a task for future research.

\section{DATA}

\section{Political Leader Survival}

To examine the relationship between climatological variables and the amount of time political leaders spend in the office we use the Archigos data set, version 4.0 (Goemans et al., 2009). Specifically, we focus on the number of days a leader spent in office and the type of exit. Given the climate and control variables data availability (see details below), we restrict our analysis to the period of $1950-2010$.

According to Goemans et al. (2009): "Leaders can lose office in 1) a regular manner, according to the prevailing rules, provisions, conventions and norms of the country, 2) an 
irregular manner, 3) through direct removal by another state, and 4) as a result of a natural death, under which we include illness or suicide" (p. 273). During the period that we study (19502010), Archigos reports a total of 1506 political leaders across all nations in the world including:

a) $991(65.8 \%)$ leaders who lost power through the regular exits,

b) $252(16.7 \%)$ losing power through irregular exits,

c) $103(6.8 \%)$ losing power through all other types of exits (e.g., natural death), and

d) $160(10.6 \%)$ leaders who are still in power.

In our presentation of the results, we focus on regular and irregular types of exit. However, other types of exits are accounted for in the competing-risks analysis that we employ (see below).

\section{Climatological Variables}

The two climate impacts that we examine here are drought and precipitation flooding. Climatological data — such as a drought index or monthly precipitation — are typically in the form of a gridded time-series dataset across the global area. A common resolution of $0.5^{\circ}$ longitude and $0.5^{\circ}$ latitude translates into a 720 by 360 grid. In order to transform the climate data to be compatible with political variables, we create annual national measures of drought and precipitation, and match the climate data with national boundaries GIS data (Bhaduri et al., 2007). For all grid cells that belong to a given country, we calculate the average climatological value for a given month ${ }^{5}$. Then we create two annual measures of a climatic impact: (a) based on the monthly mean, and (b) based on the monthly maximum.

\footnotetext{
${ }^{5}$ For grid cells that are not completely contained by a country's boundaries, we use national identification of the largest territory within the grid cell to determine the national identification of
} 
We model drought using the Standardized Precipitation-Evapotranspiration Index (SPEI), which is a drought index that is based on precipitation and temperature data (Vicente-Serrano et al., 2009) ${ }^{6}$. The SPEI time-scales can vary between 1 and 48 months. Here we explore common SPEI-12 month and SPEI-24 month measures, representing drought conditions in a given location in the past 12 and 24 months, respectively. The complete SPEI gridded time-series are publicly available at $<\underline{\text { http: } / / \text { sac.csic.es } / \text { spei } / \text { database.html }}>$. Since only the negative values of the SPEI represent drought (positive values represent above-average precipitation), we define a Drought Index variable as $D I=-S P E I$ for $S P E I<0$ and $D I=0$ for $S P E I>0$. See Table A1 in the Appendix for descriptive statistics.

Figure 1(a) shows an example of the SPEI index for Sudan, along with six major droughts that affected the country since its independence in 1956 (Reyna, 2010). The graph is based on the SPEI-12 monthly mean. As expected the lowest SPEI values are recorded for the

the cell. For coastal areas, the grid cell has a national identification of a country as long as there is at least some (no matter how small) land area within the cell.

${ }^{6}$ SPEI calculation uses the monthly difference between precipitation and potential evapotranspiration (PET). This difference between precipitation and PET describes the water balance of the soil (Thornthwaite, 1948). Although other drought indices are also based on water balance — such as the Palmer drought severity index (PDSI) (Palmer, 1965)—SPEI is more convenient to calculate and can represent different time scales. At longer timescales (e.g., 12 months), the SPEI has been shown to correlate with the self-calibrating PDSI for a set of observatories with different climate characteristics, located in different parts of the world (Vicente-Serrano et al., 2009). 
period of 1984-1985 (1984: SPEI $=-1.55 ; 1985:$ SPEI $=-1.48)$ when Sudan was affected by devastating drought and resulting famine (De Waal, 1989; Tobert, 1985).

For precipitation, we use the state-of the-art monthly precipitation data from the Climatic Research Unit dataset (Harris et al., 2014), which is the gridded time-series dataset with high resolution $\left(0.5^{\circ}\right.$ latitude $\mathrm{x} 0.5^{\circ}$ longitude grid cells $)$ across the global land areas excluding Antarctica. The unit of the precipitation data is millimeter per month. Figure 1(b) shows the mean precipitation values for Australia and the biggest floods affecting the country during 19502014 (Deo et al., 2015). Similar to our measure of drought, there is a close correspondence between the physical measure of the climatic phenomenon (drought index, millimeters of precipitation) and the climate impact affecting humans (extreme droughts/famine and devastating floods). As the figure illustrates, despite the fact that both Sudan and Australia are large countries, the climate measure based on grid cell means is an accurate measure of national impacts, even if only a part of the country is affected (e.g., floods in Australia).

(Figure 1 about here) 
FIGURE 1. (a) SPEI-12 and droughts in Sudan. (b) Precipitation and major floods in Australia.

(a)

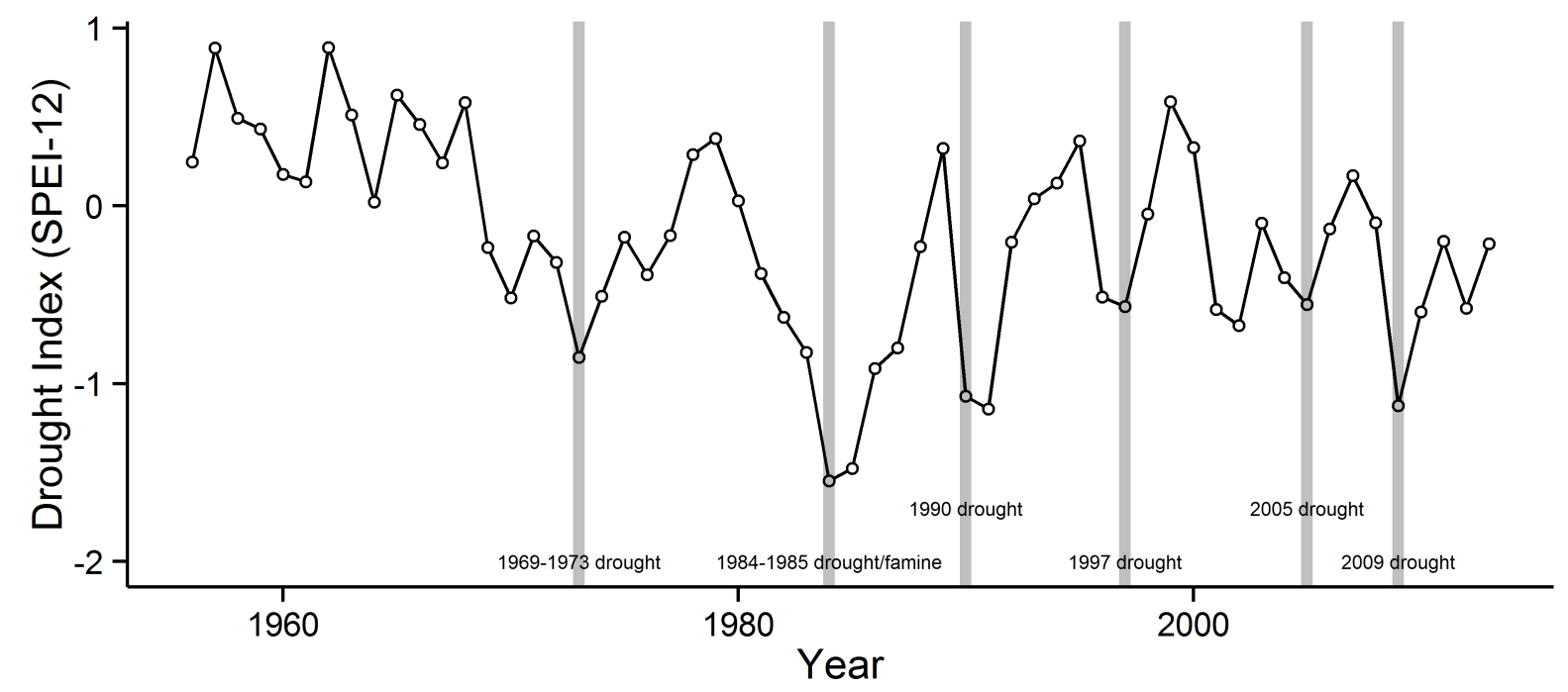

(b)

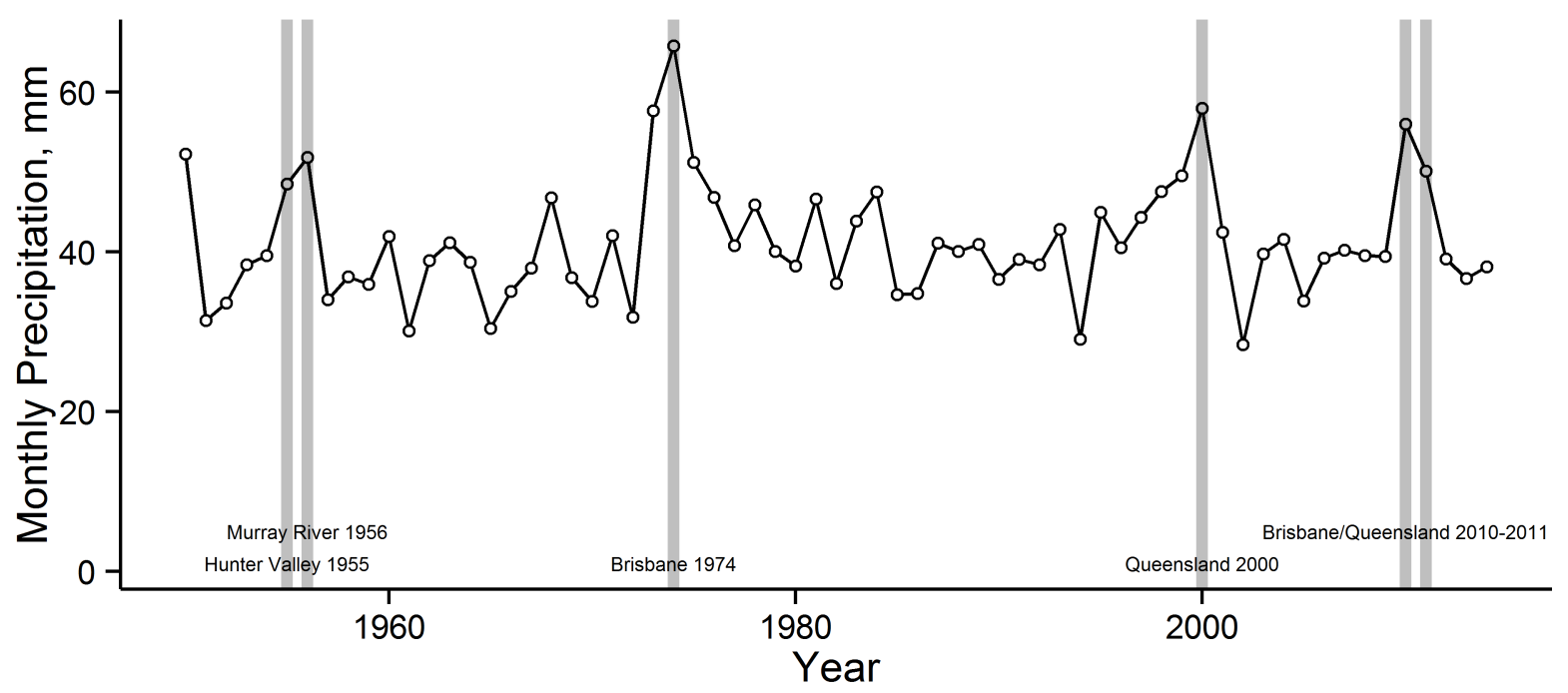




\section{Earthquakes, technological and epidemic disasters}

In this paper, we are primarily interested in the effects of droughts and flooding precipitation on political leader survival, using our newly generated "objective" georeferenced climate data for the entire world. However, it is possible that other disasters may cause an omitted variable bias if their occurrence is correlated with the extreme weather events that we study. While this is unlikely (yet possible) for earthquakes, there may be a relationship between floods/droughts, on the one hand, and technological and epidemic disasters, on the other. For example: a flood may cause spread of bacteria and drought may cause problems with sanitation facilities. Technological disasters may also be related to climate impacts if the government transfers resources and personnel from, say, equipment maintenance to address other more urgent needs associated with floods or droughts.

Therefore, as robustness check, we include additional variables in our analysis based on the Emergency Events Database (EM-DAT) database, namely, occurrence of earthquakes, technological disasters, and epidemic disasters (D. Guha-Sapir et al., 2015). As previously noted, these variables are based on reports from various agencies, non-governmental organizations, insurance companies, research institutes and mass media. In this respect, they may be associated with more noise and systematic biases ${ }^{7}$ than our climatological variables. As we show below, inclusion of these variables does not change any of our substantive results.

\footnotetext{
${ }^{7}$ For example, developed countries may have a higher rate of reporting (but not actual occurrence) of various disasters than developing countries.
} 


\section{MODEL}

To examine the impact of droughts and flooding on either regular or irregular exit, we need to estimate the cumulative incidence of political exit as a function of these two competing risks. A political leader may lose power in a regular fashion, for example through elections. However, the same leader also always faces the risk of losing office due to irregular removal by means of impeachment, coup, assassination, and so on. Since the two events prevent each other from occurring and we can only observe either a regular or an irregular exit, we need to treat the two types of exit as competing events. In this case, a competing-risks regression model is a preferred statistical model (Fine \& Gray, 1999). The competing-risks model is most commonly used in medical research since patients' deaths may have different causes (Satagopan et al., 2004; Wolbers et al., 2014).

In the present model, the competing risks of regular and irregular exits are specified as a function of (1) the drought index, (2) precipitation, (3) a political leader's age, (4) the national population (United Nations, 2013), (5) GDP per capita (Heston et al., 2012), (6) regime type based on the Polity measure (Mashall et al., 2014), and (7) the size of the territory derived from the LandScan grid (Bhaduri et al., 2007).

Notice that, in the model, we want to account for all types of exits. Therefore, for the incidence of regular exits, the competing risk includes irregular and all other types of exits (such as natural deaths), which are not regular. Similarly, for the incidence of irregular exits, the competing risk includes regular and all other types of exits, which are not irregular.

The cumulative incidence function is estimated by means of STATA's command stcreg (StataCorp, 2015, p. 152), which is based on Fine and Gray (1999):

$$
\mathrm{CIF}_{1}(t)=1-\exp \left\{-\bar{H}_{1}(t)\right\}
$$


where

(2) $\quad \bar{H}_{1}(t)=\int_{0}^{t} \bar{h}_{1}(t) d t$ is the cumulative subhazard for failure of type 1 (e.g., regular exit) with $\bar{h}_{1}(t)$ defined as the hazard for the event 1 (StataCorp, 2015, pp. 156-157).

Including a fixed-effects component in a competing-risk model is not common ${ }^{8}$. We do not include country dummies in the competing risks model for two reasons. First, we are interested in the impact of political institutions (Polity) and economic development (GDP per capita) on leader survival. Neither variable varies much within a given country over time. We therefore rely on state-level characteristics across countries. In a fixed-effects model, these differences would be absorbed by the country dummies.

Second, the ratio of the number of political leaders to the number of countries in out data is very small (8.7) and uneven: some countries experience much greater political leader turnover than others. At the same time, droughts and floods are rare events (both Sudan and Australia illustrated above, in fact, represent countries with greater than usual incidence of extreme weather events). This makes the intersection of political exit and drought/flood a very rare event.

\footnotetext{
${ }^{8}$ One exception that we could find is a study of length of stay and hospital discharge by (Sá et al., 2007). We note, however, that the ratio of the number of patients $(34,250)$ to the number of hospitals $(78)$ is much larger than the ratio of the number of leaders $(1,495)$ to the number of countries (172): 439.1 and 8.7, respectively. Even for a large number of patients relative to the number of hospitals, the authors acknowledge possible limitations associated with the fixedeffects approach.
} 
Therefore, given the nature of the variables and the sample size in our study, it is necessary to leverage cross-national comparisons as opposed to isolating events within countries.

We are aware that each country may have its own "normal" level of precipitation or drought conditions: meteorologically, what is common in India is very different from what is common in Syria. To account for such heterogeneity, we also include a measure of precipitation based on deviations from the country-specific means (similarly, the SPEI is constructed on the basis of deviations from the historical reference period).

The measure of drought used in our statistical models is based on the SPEI-12 (VicenteSerrano et al., 2009), representing drought conditions in the country in the previous 12 months (as illustrated in Figure 1(a)). We also tested alternative measures of drought based on 24, 36, and 48-month drought conditions and found substantively similar results.

Unlike drought, flooding impacts may be short-term and more intense. Therefore, for the measure of precipitation (Harris et al., 2014), we model flooding on the basis of: (a) mean monthly precipitation for the previous calendar year, and (b) maximum monthly precipitation in the previous calendar year. We do not use the measures of precipitation in the current calendar year because a leader's exit may occur in the same year as the flooding event but in an earlier month.

To make interpretation of coefficients more intuitive in the regression tables, we transformed the political regime (Polity) variable from the $[-10 ; 10]$ range to the $[0 ; 20]$ range by simply adding 10 units. Values below 5 roughly represent authoritarian regimes; values above 15 represent democracies; values between 5 and 15 describe anocracies (Mashall et al., 2014). 


\section{RESULTS}

\section{Regular Exit}

First, we examine the relationship between the climatic variables and regular political exit, with all other types of exit treated as competing risk. In Table 1, we show estimates for the cumulative incidence of regular exit. As described above, the results are based on the measure of precipitation that employs a one-year lag. Model 1 is based on the mean monthly precipitation while Model 2 uses the maximum monthly precipitation. Models 3 and 4 include interactions of precipitation and the Polity score. Finally, Model 5 replicates Model 4 but instead of using the absolute value of precipitation we use a measure that represents deviation from the countryspecific mean value for the period of 1950-2010. Model 5 is especially important in the context of Neumayer et al. (2014), who found a negative relationship between disaster propensity and economic losses. The country-specific mean precipitation for the entire period is an accurate measure of the general propensity of the country to experience flooding events. Similarly, our measure of drought is based on the Standardized Precipitation Evapotranspiration Index (SPEI), which by construction represents deviation from the historical drought conditions (VicenteSerrano et al., 2009), thus, accounting for the general drought propensity for a given country.

All of the controls have significant effects that are consistent across specifications. More populous and wealthier countries experience more regular leader turnover, whereas countries with larger territory experience less. The risk of regular removal from office also increases with the age of the leader. In our analysis, we are primarily interested in the effects of climate variables and their interaction with the political regime type and economic development. 
TABLE 1. Regular Political Exit and Historical Climate Impacts (1950 - 2010).

\begin{tabular}{|c|c|c|c|c|c|}
\hline & (1) & $(2)$ & (3) & (4) & $(5)$ \\
\hline Drought (12 months) & $\begin{array}{l}0.08407 \\
(0.10164)\end{array}$ & $\begin{array}{l}0.07459 \\
(0.10152)\end{array}$ & $\begin{array}{l}0.08156 \\
(0.10180)\end{array}$ & $\begin{array}{l}0.06906 \\
(0.10167)\end{array}$ & $\begin{array}{l}0.05903 \\
(0.10239)\end{array}$ \\
\hline Precipitation (lag, monthly mean) & $\begin{array}{l}0.00106^{\star *} \\
(0.00054)\end{array}$ & & $\begin{array}{l}0.00319^{* *} \\
(0.00159)\end{array}$ & & \\
\hline Precipitation (lag, monthly max) & & $\begin{array}{l}0.00041 \\
(0.00027)\end{array}$ & & $\begin{array}{l}0.00181^{* * *} \\
(0.00066)\end{array}$ & \\
\hline $\begin{array}{l}\text { Precipitation (lag, monthly max) } \\
\text { - deviation from the country } \\
\text { mean (1950-2010) }\end{array}$ & & & & & $\begin{array}{l}0.00284^{* * *} \\
(0.00093)\end{array}$ \\
\hline $\begin{array}{l}\text { Precipitation (lag, monthly mean) } \\
\text { x Polity }\end{array}$ & & & $\begin{array}{l}-0.00014 \\
(0.00009)\end{array}$ & & \\
\hline $\begin{array}{l}\text { Precipitation (lag, monthly max) } \\
\text { x Polity }\end{array}$ & & & & $\begin{array}{l}-0.00010^{* *} \\
(0.00004)\end{array}$ & \\
\hline $\begin{array}{l}\text { Precipitation (lag, monthly max) } \\
\text { - deviation from the country } \\
\text { mean (1950-2010) } \\
\text { x Polity }\end{array}$ & & & & & $\begin{array}{l}-0.00017^{* * *} \\
(0.00006\end{array}$ \\
\hline Polity & $\begin{array}{l}0.09383^{* * *} \\
(0.00819)\end{array}$ & $\begin{array}{l}0.09417^{\star * *} \\
(0.00817)\end{array}$ & $\begin{array}{l}0.10779^{\star * *} \\
(0.01266)\end{array}$ & $\begin{array}{l}0.11680^{\star * *} \\
(0.01254)\end{array}$ & $\begin{array}{l}0.11747^{* * *} \\
(0.01138)\end{array}$ \\
\hline Log Population & $\begin{array}{l}0.07792^{* * *} \\
(0.02933)\end{array}$ & $\begin{array}{l}0.07631^{* * *} \\
(0.02950)\end{array}$ & $\begin{array}{l}0.07802^{* * *} \\
(0.02926)\end{array}$ & $\begin{array}{l}0.07628^{* * *} \\
(0.02947)\end{array}$ & $\begin{array}{l}0.07762^{* * *} \\
(0.02962)\end{array}$ \\
\hline Log GDP per capita & $\begin{array}{l}0.10941^{* * *} \\
(0.03475)\end{array}$ & $\begin{array}{l}0.11279^{* \star *} \\
(0.03587)\end{array}$ & $\begin{array}{l}0.10723^{* * *} \\
(0.03488)\end{array}$ & $\begin{array}{l}0.10340^{* * *} \\
(0.03610)\end{array}$ & $\begin{array}{l}0.09246^{\star *} \\
(0.03640)\end{array}$ \\
\hline Log Territory (grid cells) & $\begin{array}{l}-0.05124^{* *} \\
(0.02361)\end{array}$ & $\begin{array}{l}-0.04806^{*} \\
(0.02478)\end{array}$ & $\begin{array}{l}-0.05127^{* *} \\
(0.02357)\end{array}$ & $\begin{array}{l}-0.05032^{* *} \\
(0.02484)\end{array}$ & $\begin{array}{l}-0.05640^{* *} \\
(0.02518)\end{array}$ \\
\hline Leader's Age (years) & $\begin{array}{l}0.01323^{* *} \\
(0.00328)\end{array}$ & $\begin{array}{l}0.01305^{\star * *} \\
(0.00328)\end{array}$ & $\begin{array}{l}0.01322^{* * *} \\
(0.00328)\end{array}$ & $\begin{array}{l}0.01331^{* * *} \\
(0.00329)\end{array}$ & $\begin{array}{l}0.01350^{* * *} \\
(0.00329)\end{array}$ \\
\hline Observations & 7,967 & 7,967 & 7,967 & 7,967 & 7,967 \\
\hline Subjects & 1,495 & 1,495 & 1,495 & 1,495 & 1,495 \\
\hline Failed & 981 & 981 & 981 & 981 & 981 \\
\hline Competing & 354 & 354 & 354 & 354 & 354 \\
\hline Censored & 160 & 160 & 160 & 160 & 160 \\
\hline
\end{tabular}


First, we look at drought. In all models that we examine, the drought impacts point toward a substantial risk of losing office, but the standard errors are too large for the effect to be statistically significant. The pattern is the same regardless of whether we use a version of the SPEI index that looks back 12, 24, 36 or 48 months. It appears that the slow-moving development of drought conditions does not seem to produce enough political pressure, which lends support to our Hypothesis 4.

In contrast to drought, we find that flooding precipitation increases the risk of regular removal from office in a significant manner. This effect is statistically significant for monthly means (model 1) but is estimated with less precision for the measure based on maximum observed precipitation (model 2). Adding the interaction with regime type shows that the effect of flooding varies widely between democracies and non-democracies. For both measures of precipitation, moving toward a higher democracy score (greater value of the Polity variable) reduces the impact of precipitation on the risk of leader removal (negative interaction term). Notably, the maximum observed precipitation produces highly significant coefficients (model 4), while the specification based on the mean monthly measure has greater uncertainty (model 3). Finally, we observe that using a measure of precipitation based on deviations from the countryspecific means (model 5), we obtain similar substantive results, which, in fact, have larger coefficients and greater statistical significance.

To evaluate the substantive effect of flooding and regime type on leader removal, we calculate the predicted cumulative incidence of regular removal over time (Figure 2). The cumulative incidence function (CIF) provides the probability that the event of interest happened by a given time period. For example, the CIF evaluated at 4 years gives the probability that a 
leader lost office in a regular fashion prior to finishing his $4^{\text {th }}$ year in office. ${ }^{9}$ Two results stand out. First, in line with well-established findings, democratic leaders have a higher probability of losing power via regular exit than their non-democratic counterparts. This is no surprise since regular elections and term limits are a hallmark of democracy. Second, consistent with our Hypothesis 2, democratic leaders are notably less affected by flooding precipitation than authoritarian leaders.

For democratic leaders, the risk of removal from office over time is virtually indistinguishable with and without flood conditions (empty and filled circles). In contrast, nondemocratic leaders start with a much lower baseline risk of losing office (empty squares). Flooding not only is associated with a higher likelihood of regular exit (filled squares), this effect also increases over time. For example, for a fully authoritarian leader (Polity $=0)$ who is four years in power, flooding increases the cumulative incidence of regular exit from $9.6 \%\left(5^{\text {th }}\right.$ percentile of precipitation variable) to $20.4 \%$ ( $95^{\text {th }}$ percentile of precipitation). That means that non-democratic leaders are approximately two times more likely to lose power under high precipitation than lower precipitation. For a democratic leader $($ Polity $=20)$ after four years in power, the cumulative incidence of regular exit actually slightly decreases from $62.4 \%$ under normal conditions $\left(5^{\text {th }}\right.$ percentile of precipitation) to $60.6 \%$ if there is flooding $\left(95^{\text {th }}\right.$ percentile of precipitation).

\footnotetext{
${ }^{9}$ The CIF is the appropriate quantity of interest for competing risk models. Standard survival functions are not well defined because the event of interest depends on the covariates both directly and indirectly through the effect of the covariates on competing events (Fine \& Gray, 1999).
} 
FIGURE 2. Regular Exit for Autocracy and Democracy under Low and High Precipitation.

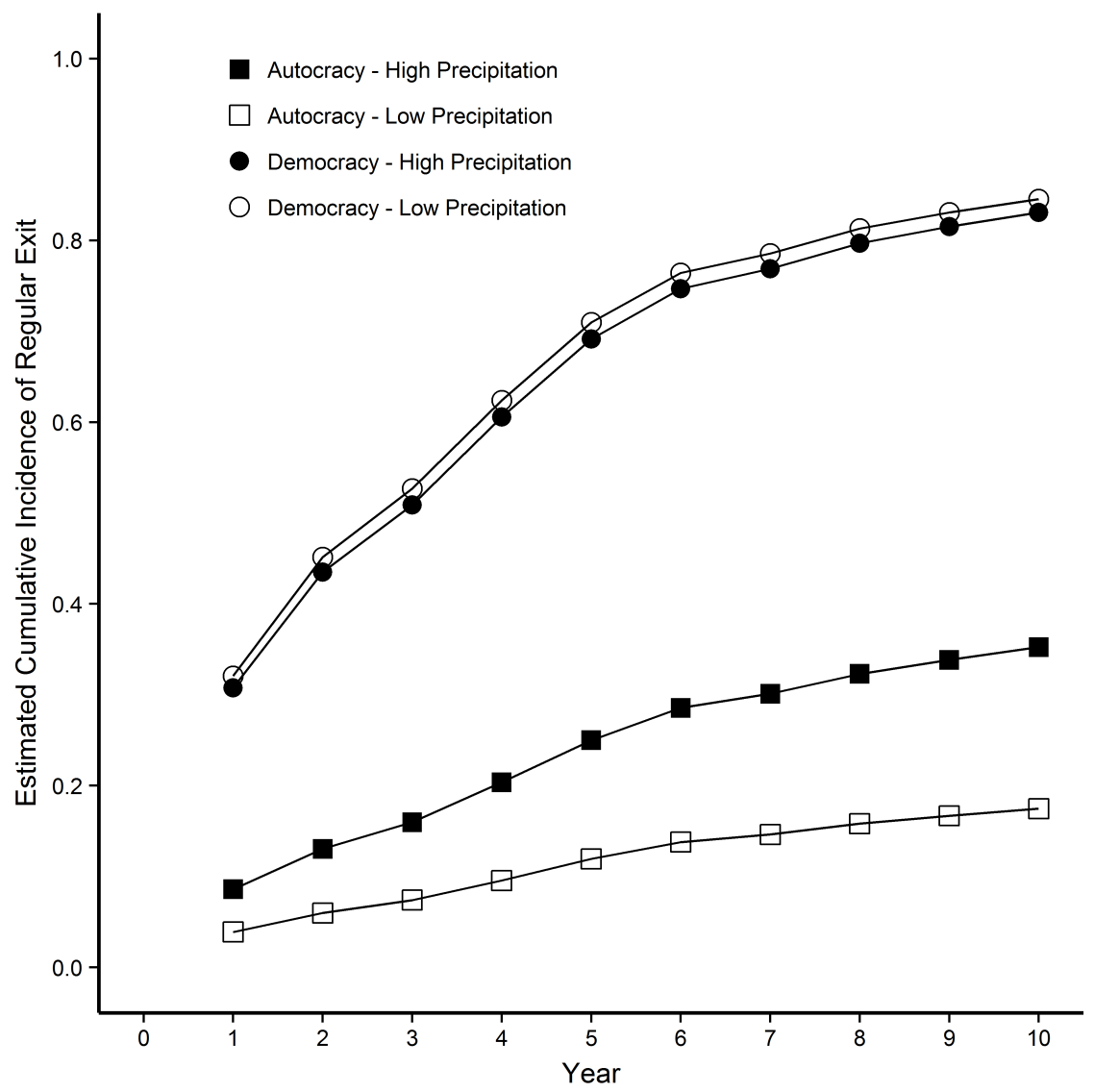

Note: The cumulative incidence function is calculated on the basis of Model 4 in Table 1.

Evaluating the uncertainty with which these effects are estimated is not straightforward. Gray (1988) describes a formal test for differences in CIFs, but the test does not allow for incorporation of covariates. As an alternative, we turn to a parametric bootstrap procedure that relies on re-sampling from the sampling distribution (King et al., 2000). Figure 3 shows the difference in the cumulative incidence for authoritarian regimes (lowest Polity value) with and without precipitation and provides a 95 percent confidence band. The confidence band does not contain the origin, establishing that in autocracies the effect of precipitation on regular removal from office is statistically significant.

(Figure 3 about here) 
FIGURE 3. Difference in the cumulative incidence of regular exit for non-democracies with and without precipitation.

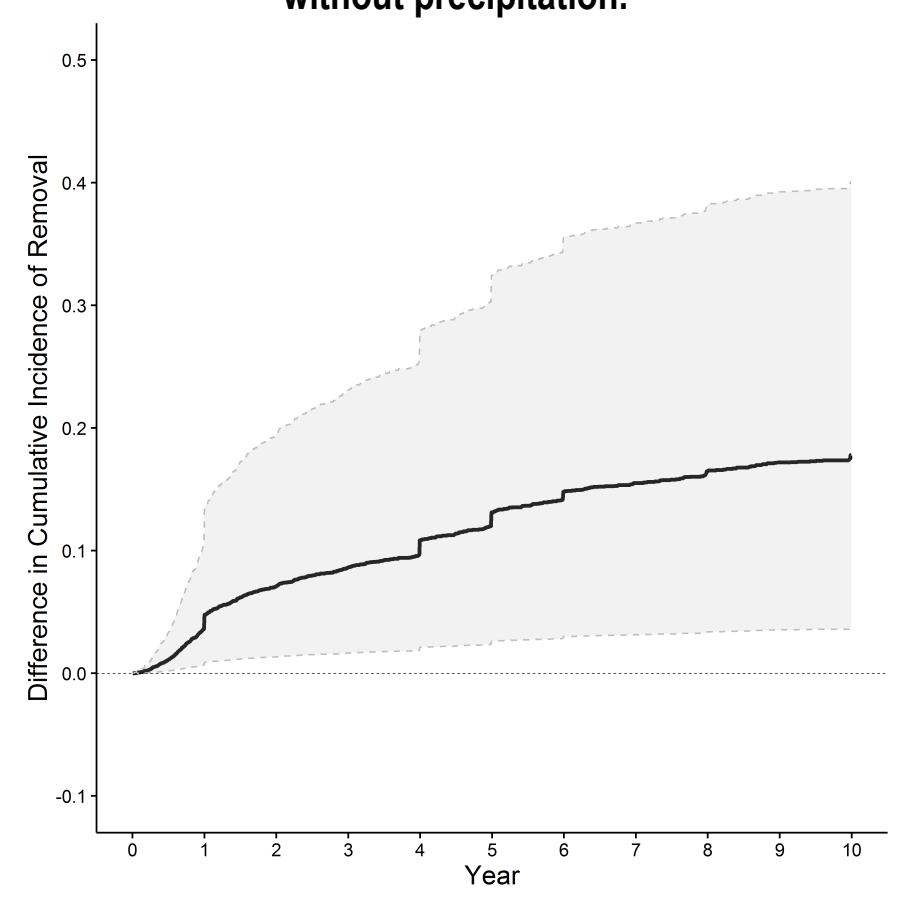

Note: Shaded regions represent 95\% confidence intervals.

In the discussion so far, we dichotomized the difference between democratic and nondemocratic leaders. In Figure 4 we summarize the substantive effects of flooding precipitation across the entire range of the Polity variable. As before, effect sizes are based on calculating the difference in the cumulative incidence of removal from office comparing the $5^{\text {th }}$ and $95^{\text {th }}$ percentiles of the precipitation variable.

Figure 4 shows that flooding precipitation has a substantial and statistically significant effect on regular removal from office across a large part of the Polity range, including autocracies and anocracies. Only the political survival of fully democratic rulers is not affected by flooding in a statistically discernable manner. Autocracies experience the largest effects, with precipitation increasing the risk of losing office by approximately 10 percentage points. 
FIGURE 4. Difference in the cumulative incidence of regular exit with and without precipitation after four years in the office.

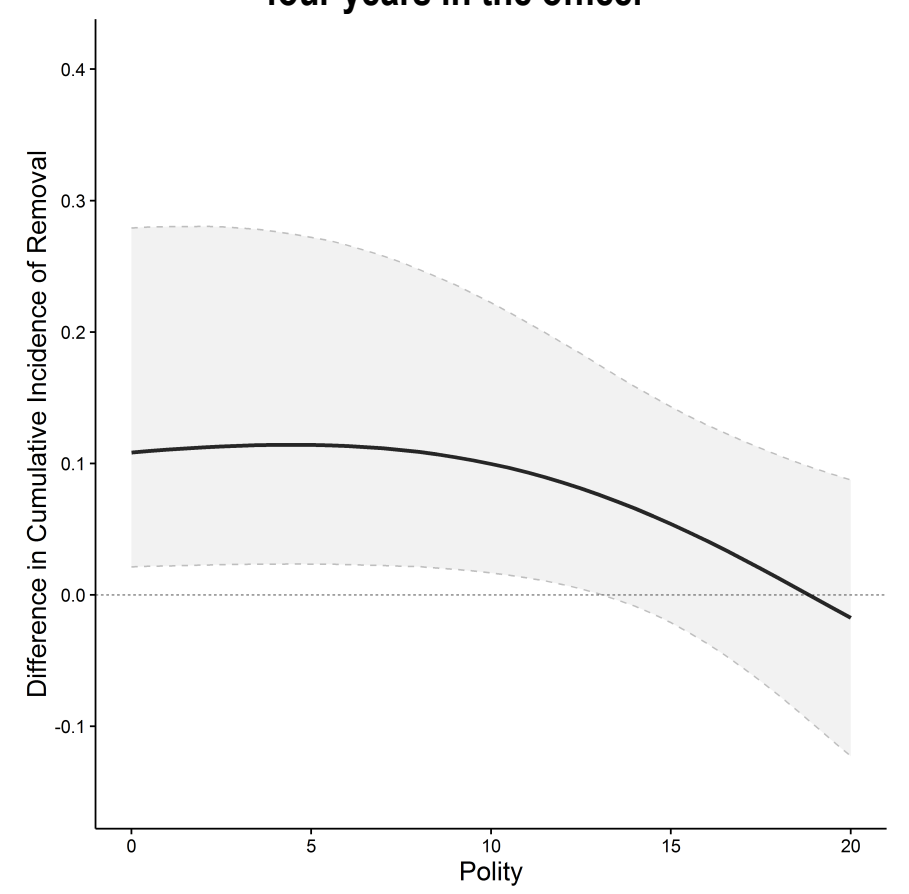

Note: Shaded regions represent 95\% confidence intervals.

In addition to the baseline specification above, we conducted a number of robustness checks which can be found in the Appendix. First, we included other disasters in the model (namely, earthquakes, technological disasters, and epidemic disasters), with and without lag (Table A2). Second, we included an additional ( $t-2)$ lag to model 4 (Table A3). Finally, we interacted leader age with regime type (Table A4). All of our substantive results remain statistically significant.

We repeat the analysis of the effects of flooding precipitation and drought on regular removal from exit, but this time we include interactions between the climate variables and GDP per capita, as a measure of economic development. We find no evidence that a country's wealth moderates the effects of drought or flooding on leader survival in a significant manner (Table A5 in the Appendix). 
This result contradicts our intuition described in Hypothesis 3, which therefore is not supported. The lack of an interaction between GDP per capita and climate impacts is important in the context of the literature on development and vulnerability to natural disasters in economics (e.g., Kahn (2005)). Our findings imply that political institutions - rarely accounted for in statistical models by economists - may play an important role for climate impacts. This is especially important since economic development and political institutions are positively correlated (in our data, Polity and GDPPC have $r=0.42$, Polity and $\log (G D P P C)$ have $r=$ 0.50). When establishing a relationship between economic development and environmental adaptive capacity, economists may in fact be capturing the effect of political institutions.

\section{Irregular Exit}

We now examine the relationship between the climatic variables and irregular political exit, with regular and other types of exit modelled as competing risks. In terms of climate impacts, irregular exit results resemble the patterns observed for regular exit (Table A6 in the Appendix). However, the coefficients are not statistically significant, including the measures based on maximum monthly precipitation. Similarly, the effect of drought is consistently in the direction that we expected, but the standard errors are too large. The interaction between climate variables and GDP per capita also remain insignificant (Table A7).

Therefore, we find support for Hypothesis 1 only for regular exit but not for irregular exit. Nevertheless, we note that the number of irregular exits in our data is much smaller than the number of regular exits for the same period and set of countries: 251 irregular exits vs. 981 regular exits. Therefore, it is possible that we are unable to establish a significant relationship between extreme weather events and irregular exits because the latter are rare events (at least, relative to the incidence of regular exits). 
The weakly significant interaction between precipitation and regime type (model 3) suggests that, in terms of irregular exit, authoritarian leaders might be more vulnerable to climate impacts than democratic leaders. However, since the effect is below conventional levels of statistical significance, we are unable to argue that there is a systematic relationship between flooding precipitation and irregular removal from office.

\section{DISCUSSION}

Our main results are summarized in Table 2. Extreme weather events increase the likelihood of regular removal for non-democratic leaders in the case of sudden natural disasters such as flooding precipitation. We are unable to make the same conclusion in the context of irregular removal, but the null result in the latter case may be due to a small number of cases since both extreme weather events and irregular removal are rare. Democratic leaders are less vulnerable to extreme precipitation. Finally, both types of leaders are not affected by the type of slow moving disaster that we study here, droughts. These results lend support to our theory outlined above: democratic leaders invest more in disaster mitigation/adaptation due to the frequent nature of political leader turnover in democracies. Non-democratic leaders under-invest in disaster-related policies since they are primarily concerned with irregular removal from office and will only address the issue if disaster-related irregular removal becomes probable. 
TABLE 2. SUMMARY OF THE RESULTS.

\begin{tabular}{|l|c|}
\hline \multicolumn{1}{|c|}{ Hypothesis } & \multicolumn{1}{c|}{ Results/support } \\
\hline H1: Extreme weather events increase the risk of removal from office. & $\begin{array}{c}\text { Supported for flooding precipitation. } \\
\text { Not supported for droughts. }\end{array}$ \\
\hline $\begin{array}{l}\text { H2: Extreme weather events have a greater effect on the risk of regular } \\
\text { removal from office in non-democratic societies. }\end{array}$ & $\begin{array}{c}\text { Supported for flooding precipitation. } \\
\text { Not supported for droughts. }\end{array}$ \\
\hline $\begin{array}{l}\text { H3: Leaders in wealthier societies are less at risk from regular or irregular } \\
\text { removal following extreme weather events than those in poorer societies. }\end{array}$ & Not supported. \\
\hline $\begin{array}{l}\text { H4: Non-democratic leaders are more vulnerable to sudden natural } \\
\text { disasters (such as flooding precipitation) than democratic leaders. }\end{array}$ & Supported. \\
\hline
\end{tabular}

Thus, our results indicate that extreme whether events don't affect leader survival in a direct manner. Instead, political regime type (democracy or non-democracy) determines whether such events make leader removal more likely. However, it should be noted that we do not describe how disaster mitigation policies differ from one country to another. This is beyond the score of the present paper. Other scholars have suggested how various political institutions may respond to disaster damage (Flores \& Smith, 2013; Lazarev et al., 2014). Those approaches, nevertheless, require reliance on data different from the (objective) georeferenced climate variables that we introduce here.

The finding of a differential effect of flooding depending on regime type, as potentially important implications for the future study of reactions to climate change and political pressures for adaptation. As first step to understanding these, how do we explain the greater effect of flooding on autocratic leaders? Since we control for wealth in our analysis, the democracy variable is not simply a proxy for development and state capacity. In fact, unlike political regime type (Polity), GDP per capita does not have a significant interaction with climate impacts when predicting political exit. As regular leader turnover in democracies often implies a political realignment and a change of the winning coalition, democratic leaders might face greater incentives to avoid even comparatively small political risks associated with flooding. This is in 
line with the existing evidence that democracies have a greater interest in disaster preparedness (Flores \& Smith, 2013) and suggests more successful efforts to adapt to the challenges of climate change.

For regular exit in non-democratic regimes, a possible interpretation of the findings is that regime leaders anticipate pressures for irregular removal in the wake of catastrophe and seek to preempt this outcome. In the face of popular pressures, changing leadership within the existing institutional structure might be preferable to political upheaval and irregular removal from office. In autocratic regimes, leader change by regular institutional venues mostly means that power remains in the hands of an inner governing circle (i.e., the "winning coalition" (Bueno de Mesquita et al., 2003)), whereas the figure head of government is exchanged. Leader change therefore might be a viable option that can help preserve the regime in power despite popular pressures. Prior research argued that non-democratic governments invest less in disaster prevention because they are less sensitive to the political costs of high human casualty numbers (Flores \& Smith, 2013). Our findings suggest that preparation might also be lacking because political pressures from flooding are effectively dealt with by changes in leadership, keeping existing institutional structures untouched.

An unexpected result of our analysis is the lack of a relationship between economic development and climate impacts. Contrary to our Hypothesis 3, leaders in wealthy and poor societies have similar risks of removal from office following extreme weather events. The same is not true for leaders of democratic and non-democratic societies. Our results show that political institutions play a more important role for the political survival of leaders whose countries are affected by floods than economic development. Since political institutions and economic development are positively correlated, many econometric models in the literature on economic 
development and environmental vulnerability (e.g., Kahn 2005) may actually capture the effect of political institutions as opposed to wealth.

From a policy perspective, our results are important because precipitation flooding is expected to increase in the $21^{\text {st }}$ century under both optimistic and pessimistic climate scenarios; certainly more so under the high greenhouse gas emissions scenario leading to abrupt climate change (Hirabayashi et al., 2013). In the context of the Paris Agreement (UNFCCC COP, 2015), adopted by 197 nations in December 2015, our results imply that there are additional political costs should the agreement not succeed. An increase in the incidence and severity of flooding will put greater pressures on leaders in democratic nations to find adaptation strategies or risk losing power. Even more dramatic will be the impact of floods on autocratic leaders. Our model predicts high leader turnover, but the consequences of this for the stability of autocratic regimes are hard to predict. It is possible that under greater environmental stress the ability to vent political pressures through regular leader exchanges diminishes, and political instability results. 


\section{REFERENCES}

Acemoglu, D., Johnson, S., \& Robinson, J. A. (2001). The Colonial Origins of Comparative Development: An Empirical Investigation. American Economic Review, 91(5), 13691401.

Achen, C. H., \& Bartels, L. M. (2004). Blind retrospection. Electoral responses to drought, flu, and shark attacks. Estudios/Working Papers (Centro de Estudios Avanzados en Ciencias Sociales)(199).

Ashley, S. T., \& Ashley, W. S. (2008). Flood Fatalities in the United States. Journal of Applied Meteorology and Climatology, 47(3), 805-818. doi:10.1175/2007JAMC1611.1

Bechtel, M. M., \& Hainmueller, J. (2011). How Lasting Is Voter Gratitude? An Analysis of the Short- and Long-Term Electoral Returns to Beneficial Policy. American Journal of Political Science, 55(4), 852-868. doi:10.1111/j.1540-5907.2011.00533.x

Beck, N., Katz, J. N., \& Tucker, R. (1998). Taking Time Seriously: Time-Series-Cross-Section Analysis with Binary Dependent Variable. American Journal of Political Science, 42(4), $1260-1288$.

Bhaduri, B., Bright, E., Coleman, P., \& Urban, M. (2007). LandScan USA: a high-resolution geospatial and temporal modeling approach for population distribution and dynamics. GeoJournal, 69(1-2), 103-117. doi:10.1007/s10708-007-9105-9

Black, R., Adger, W. N., Arnell, N. W., Dercon, S., Geddes, A., \& Thomas, D. (2011). The effect of environmental change on human migration. Global Environmental Change, 21, Sl(0), S3-S11. doi:http://dx.doi.org/10.1016/j.gloenvcha.2011.10.001

Brakenridge, G. R. (2014). Global Active Archive of Large Flood Events. Retrieved from: http://floodobservatory.colorado.edu 
Bueno de Mesquita, B., \& Smith, A. (2009). Political Survival and Endogenous Institutional Change. Comparative Political Studies, 42(2), 167-197.

Bueno de Mesquita, B., Smith, A., Siverson, R. H., \& Morrow, J. D. (2003). The Logic of Political Survival. Cambridge, MA: MIT Press.

Buhaug, H. (2010). Climate not to blame for African civil wars. Proceedings of the National Academy of Sciences, 107(38), 16477-16482. doi:10.1073/pnas.1005739107

Burkett, M. (2012). Climate Refugees. In S. Alam, Bhuiyan, J. H., Chowdhury, T. M., \& Techera, E. J. (Ed.), Routledge handbook of international environmental law: Routledge.

Chang, C.-P., \& Berdiev, A. N. (2015). Do natural disasters increase the likelihood that a government is replaced? Applied Economics, 47(17), 1788-1808. doi:10.1080/00036846.2014.1002894

Chiozza, G., \& Goemans, H. E. (2004). International conflict and the tenure of leaders: Is war still ex post inefficient? American Journal of Political Science, 48(3), 604-619.

D. Guha-Sapir, R. Below, \& Hoyois, P. (2015). EM-DAT: International Disaster Database. Retrieved from: http://www.emdat.be

De Waal, A. (1989). Famine mortality: a case study of Darfur, Sudan 1984-5. Population Studies, 43(1), 5-24.

Deo, R. C., Byun, H.-R., Adamowski, J. F., \& Kim, D.-W. (2015). A Real-time Flood Monitoring Index Based on Daily Effective Precipitation and its Application to Brisbane and Lockyer Valley Flood Events. Water Resources Management, 29(11), 4075-4093. doi:10.1007/s11269-015-1046-3

Ferejohn, J. (1986). Incumbent Performance and Electoral Control. Public Choice, 50, 5-25. 
Fine, J., P., \& Gray, R. J. (1999). A Proportional Hazards Model for the Subdistribution of a Competing Risk. Journal of the American Statistical Association, 94(446), 496-509. doi:10.2307/2670170

Flores, A. Q., \& Smith, A. (2013). Leader Survival and Natural Disasters. British Journal of Political Science, 43(4), 821-843.

Goemans, H. E. (2008). Which Way Out? The Manner and Consequences of Losing Office. Journal of Conflict Resolution, 52(6), 771-794.

Goemans, H. E., Gleditsch, K. S., \& Chiozza, G. (2009). Introducing Archigos: A Dataset of Political Leaders. Journal of Peace Research, 46(2), 269-283. doi:10.1177/0022343308100719

Harris, I., Jones, P. D., Osborn, T. J., \& Lister, D. H. (2014). Updated high-resolution grids of monthly climatic observations - the CRU TS3.10 Dataset. International Journal of Climatology, 34(3), 623-642. doi:10.1002/joc.3711

Healy, A., \& Malhotra, N. (2009). Myopic Voters and Natural Disaster Policy. The American Political Science Review, 103(3), 387-406.

Heston, A., Summers, R., \& Aten, B. (2012). Penn World Table Version 7.1.

Hirabayashi, Y., Mahendran, R., Koirala, S., Konoshima, L., Yamazaki, D., Watanabe, S., . . . Kanae, S. (2013). Global flood risk under climate change. Nature Clim. Change, 3(9), 816-821.

Hsiang, S. M., Burke, M., \& Miguel, E. (2013). Quantifying the Influence of Climate on Human Conflict. Science, 341(6151). doi:10.1126/science.1235367

IPCC. (2014). Climate Change 2014: Impacts, Adaptation, and Vulnerability. Part A: Global and Sectoral Aspects. Contribution of Working Group II to the Fifth Assessment Report 
of the Intergovernmental Panel on Climate Change. Retrieved from Cambridge, United Kingdom and New York, NY, USA:

Javeline, D. (2014). The Most Important Topic Political Scientists Are Not Studying: Adapting to Climate Change. Perspectives on Politics, 1-15.

Jonkman, S. N., \& Kelman, I. (2005). An Analysis of the Causes and Circumstances of Flood Disaster Deaths. Disasters, 29(1), 75-97. doi:10.1111/j.0361-3666.2005.00275.x

Kahn, M. E. (2005). The Death Toll from Natural Disasters: The Role of Income, Geography, and Institutions. The Review of Economics and Statistics, 87(2), 271-284.

Kelley, C. P., Mohtadi, S., Cane, M. A., Seager, R., \& Kushnir, Y. (2015). Climate change in the Fertile Crescent and implications of the recent Syrian drought. Proceedings of the National Academy of Sciences. doi:10.1073/pnas.1421533112

King, G., Tomz, M. R., \& Wittenberg, J. (2000). Making the Most of Statistical Analyses: Improving Interpretation and Presentation. American Journal of Political Science, 44(2), 347-361.

Kirsch, T. D., Wadhwani, C., Sauer, L., Doocy, S., \& Catlett, C. (2012). Impact of the 2010 Pakistan floods on rural and urban populations at six months. PLoS currents, 4.

Komori, D., Nakamura, S., Kiguchi, M., Nishijima, A., Yamazaki, D., Suzuki, S., .. . Oki, T. (2012). Characteristics of the 2011 Chao Phraya River flood in central Thailand. Hydrological Research Letters, 6(0), 41-46.

Lazarev, E., Sobolev, A., Soboleva, I. V., \& Sokolov, B. (2014). Trial by Fire: A Natural Disaster's Impact on Support for the Authorities in Rural Russia. World Politics, 66(04), 641-668. 
Licht, A. (2010). Coming into Money: The Impact of Foreign Aid on Leader Survival. Journal of Conflict Resolution, 54(1), 58-87.

Mashall, M. G., Gurr, T. R., \& Jaggers, K. (2014). Polity IV Project. Retrieved from: http://www.systemicpeace.org/inscrdata.html

Mavromatis, T. (2007). Drought index evaluation for assessing future wheat production in Greece. International Journal of Climatology, 27(7), 911-924. doi:10.1002/joc.1444

McLeman, R., \& Smit, B. (2006). Migration as an Adaptation to Climate Change. Climatic Change, 76(1-2), 31-53. doi:10.1007/s10584-005-9000-7

Mishra, A. K., \& Singh, V. P. (2010). A review of drought concepts. Journal of Hydrology, 391(1-2), 202-216. doi:http://dx.doi.org/10.1016/j.jhydrol.2010.07.012

Mishra, A. K., \& Singh, V. P. (2011). Drought modeling - A review. Journal of Hydrology, 403(1-2), 157-175. doi:http://dx.doi.org/10.1016/j.jhydrol.2011.03.049

Morrison, K. M. (2009). Oil, Nontax Revenue, and the Redistributional Foundations of Regime Stability. International Organization, 63(1), 107-138.

Neumayer, E., Plümper, T., \& Barthel, F. (2014). The political economy of natural disaster damage. Global Environmental Change, 24(Supplement C), 8-19. doi:https://doi.org/10.1016/j.gloenvcha.2013.03.011

Palmer, W. C. (1965). Meteorological Drought: U.S. Department of Commerce, Weather Bureau.

Perch-Nielsen, S., Bättig, M., \& Imboden, D. (2008). Exploring the link between climate change and migration. Climatic Change, 91(3-4), 375-393. doi:10.1007/s10584-008-9416-y

Prudhomme, C., Giuntoli, I., Robinson, E. L., Clark, D. B., Arnell, N. W., Dankers, R., . . . Wisser, D. (2014). Hydrological droughts in the 21 st century, hotspots and uncertainties 
from a global multimodel ensemble experiment. Proceedings of the National Academy of Sciences, 111(9), 3262-3267. doi:10.1073/pnas.1222473110

Reyna, S. P. (2010). The Disasters of War in Darfur, 1950-2004. Third World Quarterly, 31(8), 1297-1320. doi:10.1080/01436597.2010.541083

Ross, M. L. (2001). Does Oil Hinder Democracy? World Politics, 53(3), 325-361.

Sá, C., Dismuke, C. E., \& Guimarães, P. (2007). Survival analysis and competing risk models of hospital length of stay and discharge destination: the effect of distributional assumptions. Health Services and Outcomes Research Methodology, 7(3), 109-124. doi:10.1007/s10742-007-0020-9

Satagopan, J. M., Ben-Porat, L., Berwick, M., Robson, M., Kutler, D., \& Auerbach, A. D. (2004). A note on competing risks in survival data analysis. British Journal of Cancer, 91(7), 1229-1235. doi:10.1038/sj.bjc.6602102

Solow, A. R. (2013). Global warming: A call for peace on climate and conflict. Nature, 497(7448), 179-180. doi:10.1038/497179a

StataCorp. (2015). STATA Survival Analysis Reference Manual Release 14. College Station, TX: Stata Press.

Steinwand, M. C. (2014). Foreign Aid and Political Stability. Conflict Management and Peace Science. doi:doi:10.1177/0738894214541227

Svoboda, M., LeComte, D., Hayes, M., Heim, R., Gleason, K., Angel, J., . . Stooksbury, D. (2002). The Drought Monitor. Bulletin of the American Meteorological Society, 83(8), 1181-1190. 
Taylor, K. E., Stouffer, R. J., \& Meehl, G. A. (2011). An Overview of CMIP5 and the Experiment Design. Bulletin of the American Meteorological Society, 93(4), 485-498. doi:10.1175/BAMS-D-11-00094.1

Thornthwaite, C. W. (1948). An Approach toward a Rational Classification of Climate. Geographical Review, 38(1), 55-94. doi:10.2307/210739

Tobert, N. (1985). The effect of drought among the Zaghawa in northern Darfur. Disasters, 9(3), 213-223.

UNFCCC COP. (2015). Adoption of the Paris Agreement.: United Nations Office at Geneva | Geneva (Switzerland).

United Nations, D. o. E. a. S. A., Population Division. (2013). World Population Prospects: The 2012 Revision. Retrieved from: http://esa.un.org/wpp/Excel-Data/population.htm

Vicente-Serrano, S. M., Beguería, S., \& López-Moreno, J. I. (2009). A Multiscalar Drought Index Sensitive to Global Warming: The Standardized Precipitation Evapotranspiration Index. Journal of Climate, 23(7), 1696-1718. doi:10.1175/2009JCLI2909.1

Wolbers, M., Koller, M. T., Stel, V. S., Schaer, B., Jager, K. J., Leffondré, K., \& Heinze, G. (2014). Competing risks analyses: objectives and approaches. European Heart Journal. 